\section{Cloaca-vent prolapsed in a Lutino fischer's love bird (Agapornis fischeri)}

Dibyendu Biswas, 1

Abul Kashem Mohammed Seifuddin²

1Department of Medicine, Surgery and Obstetrics Faculty of Animal Science and Veterinary Medicine, Patuakhali Science and Technology University, Khanpura, Babugonj, Barisal; ${ }^{2}$ Teaching Veterinary Hospital, Chittagong Veterinary and Animal Sciences University, Pahartali, Chittagong, Bangladesh

\section{Abstract \\ Cloacal-vent prolapse in a bird is often fatal if left untreated. A 10-month-old female love bird was brought to teaching veterinary hospital, Chittagong Veterinary and Animal Sciences University, Bangladesh, due to an everted cloaca through the vent. This condition was treated suc- cessfully by washing, massage, and icing. Calcium was supplemented orally for five days and the bird was cured completely after seven days.}

\section{Introduction}

The avian cloaca is a unique and serves as a common opening for the urinary, reproductive and gastrointestinal tracts. A cloacal prolapse may result from severe constipation and toxemia and is not uncommon in captive birds. It occurs often in laying hens and can occur before, during or immediately after egg laying. Severe cases of cloacal prolapse are usually fatal. ${ }^{1}$ However, this condition appears to be most common in Old World psittacine birds, especially cockatoos and is associated with reduced sphincter tone, such as that caused by chronic gram-negative enteritis. ${ }^{2}$ This is mostly seen in young birds several days to 4 weeks old. It is interesting to note that the cloaca prolapses normally in the Vasa Parrot during the breeding season. In some cases, this may be associated with diarrhea, or more frequently, with tenesmus due to constipation. However, cloacal-vent prolapse in a love bird has not been recorded previously in veterinary science at Bangladesh. Mineral deficiency; e.g. hypocalcemia, is one important initiating factor. ${ }^{3}$ During the laying period, larger amounts of calcium are required for egg-shell production than in normal conditions, leading to hypocalcemia, which weakens muscle contraction. Also, the uterus is often unable to contract sufficiently to lay the eggs, and the cloa- cal sphincter muscle may be too weak to remain closed. 4

However, there is very limited information about the treatment of cloacal-vent prolapse in pet bird such as love bird and herein, we describe a treatment method of cloacal-vent prolapse in pet birds. In gallinaceous birds, cannibalism by cage mates may result in cloacal rupture and evisceration of the affected individual. A female Lutino Fischer's Love bird was presented to the SA Quaderi Teaching Veterinary Hospital (SAQTVH), Chittagong Veterinary and Animal Sciences University (CVASU), Chittagong, Bangladesh due to an inflamed cloacal-vent prolapse that had been noticed 6 hour previously. Therefore, the present study was to discuss about the treatment strategy of cloacal-vent prolapsed in a love bird.

\section{Case Report}

A 10-month-old female of love bird (Agapornis fischeri) was admitted to SAQTVH due to an everted cloaca through vent (Figure 1). Lubrication of the vent was attempted to relieve this condition but was unsuccessful. On physical examination, the bird was alert and responsive but was agitated and anorexic. It was also slightly dehydrated and one part of the digestive tract, which had everted through the vent was congested and hanging loose. The bird was anesthetized via inhalation of isoflurane from a piece of cotton in a wide-mouth bottle. After complete anesthesia, the everted tissues were flushed with cold saline and covered with a sterile lubricating ointment (Hexitane $^{\circledR}$, ACI Limited, Bangladesh). The everted part was iced, gently replaced into the appropriate position (Figure 2), and fixed in place using silk simple interrupted sutures. Postoperatively, the bird was housed in an individual cage and calcium (Tab. Caltate, Reneta Ltd, Bangladesh) was supplemented through the drinking water for 5 days. The sutures were removed after 5 days and after 7 days the bird was successfully cured without any signs of discomfort (Figure 3).

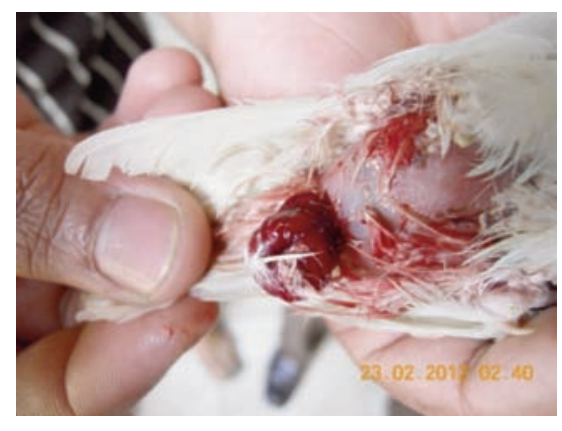

Figure 1. Prolapsed cloaca-vent and congested mucus layer.
Correspondence: Dibyendu Biswas, Department of Medicine, Surgery and Obstetrics Faculty of Animal Science and Veterinary Medicine, Patuakhali Science and Technology University, Babugonj, Barisal 8210, Bangladesh.

Tel. +88.019.131.12042.

E-mail: dibyenducvasu@gmail.com

Key words: Love bird, vent prolapse, Bangladesh.

Contributions: the authors contributed equally.

Received for publication: 21 0ctober 2013.

Revision received: 8 December 2013

Accepted for publication: 19 December 2013

This work is licensed under a Creative Commons Attribution NonCommercial 3.0 License (CC BYNC 3.0).

(C)Copyright D. Biswas and A.K.M. Saifuddin, 2014 Licensee PAGEPress srl, Italy

Veterinary Science Development 2014; 4:5141 doi:10.4081/vsd.2014.5141

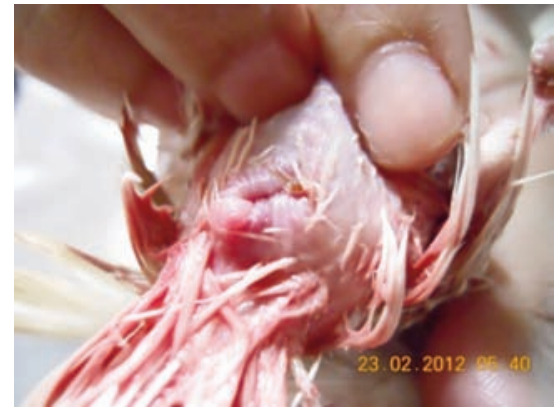

Figure 2. After correction of prolapsed part was replaced properly.

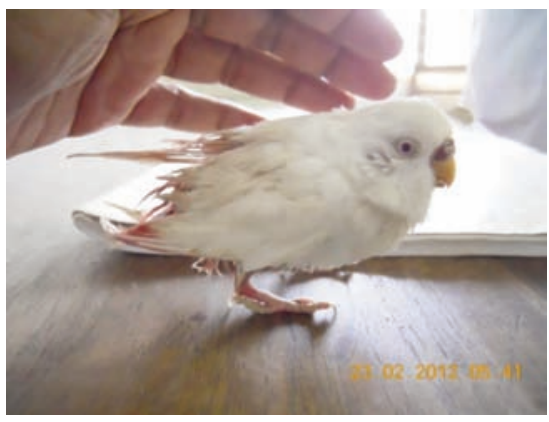

Figure 3. Normal apparance of this love bird after successfully correction of this condition. 


\section{Discussion and Conclusions}

Cloacal-vent prolapse is associated with the inner tissues of the cloaca hanging out of the vent, consequently exposing the intestines, cloaca and/or uterus to the environment. 5 The exact etiology of this condition is unclear but can be due to either a gastrointestinal tract or reproductive tract abnormality. Intestinal parasites, constipation, or similar problems can cause prolapse secondary to GI issues; masturbation, sexual frustration, or egg problems in females can cause prolapse due to reproductive reasons.

Our study is the first report of cloacal-vent prolapse in a love (Agapornis fischeri) bird and successful treatment of this condition via a standard protocol. Two birds of 10 months old were reared in case conditions and fed cereal regularly without any supporting nutrients or other vitamins. Fresh water was supplied ad libitum daily. Cloacal prolapse in these birds was unpredictable and the causes remain undefined. Restricted hand-feeding could initiate this condition, which is then aggravated by nutrient deficiency. According to the history provided by the owner, male birds had frequently attempted to mate with the female love bird, which could have led to this condition.

In summary, isoflurane was used for inhalational gas anesthesia instead of carbon monoxide due to possible toxicity to the bird. ${ }^{6}$ The inflamed part of the cloacal tissue was iced, lubricated, and the prolapse was replaced properly, after which the veterinarian awaited oviposition. The everted part was then sutured to prevent recurrence of the condition. Calcium was supplemented for 5 days, after which the condition was cured. The calcium likely improved muscle fiber tone. ${ }^{7}$

Although hand-fed birds are more likely to develop cloacal prolapse, misplaced sexual attraction from males also causes stretching and opening of the vent that can lead to vent/cloacal prolapse. This condition can also be initiated by straining from constipation. Vent prolapse is a common problem in a laying bird in farm conditions. ${ }^{8}$ In this situation, most cases are due to poor feed management practices. However, during egg-laying, the oviduct is pushed through the cloaca and retracts after the egg is laid. Failure to retract the oviduct and a part of the oviduct remains outside the body and bloody tissue can be seen protruding from the vent. Young birds are more susceptible to this condition. In our study, the bird was 10 months old, and the results were supported by other reports; the condition is known as bloody vent in chickens. ${ }^{9}$ Hens that are overweight, older or very young or have oversized eggs are predisposed to the condition. It is difficult to cure because as the bird continues to lay and the oviduct exits the cloaca repeatedly, another bird sometimes pecks the inflamed tissue, inflicting damage.

In conclusion, the current report is the first to detail successful management of a cloacal-vent prolapse in a love bird. Calcium preparation can improve this condition and aid healing.

\section{References}

1. Clipsham R. Introduction to psittacine pediatrics. Vet Clin N Am Sm Anim Pract 1991;21:1361-92.

2. Avgeris S, Rigg D. Cloacopexy in a sulphurcrested cockatoo. J Am Anim Hosp Assoc 1988;24:407-10.

3. Scheideler SE. 2007. Canabolism by poultry. NebGuide. Availble from: http://extension.enl.edu/publications.

4. Martin T. 2008. Prolapsed cloaca. Available from: http://www.avianweb.com.

5. Quesenberry KE, Hillyer EV. Supportive care and emergency therapy. In: Ritchie BW, Harrison GJ, Harrison LR, eds. Avian medicine: principles and applications. Lake Worth: Wingers; 1994. pp 382-6.

6. Reilly JS. Euthanasia of animals used for scientific purposes. 2nd ed. Enzccart, Adelaide, SA 5005; 2001.

7. Javdani M, Nikousefat Z. Surgical removal of oviduct due to egg retention in a budgerigar (Melopsittacus undulatus): a case report. Res Opin Anim Vet Sci 2012;2:148-50.

8. Newberry RC. Cannibalism. In: Perry GC, eds. Welfare of the laying hen. Wallingford: CABI Publishing; 2004. pp 239-58.

9. Lumeij JT. Gastroenterology. In: Ritchie BW, Harrison GJ, Harrison LR, eds. Avian medicine: principles and application. Lake Worth: Wingers Publishing Inc.; 1994. p 501. 